\title{
1. Opportunities and challenges for post-Keynesian economics?
}

\section{Sheila Dow}

\subsection{INTRODUCTION}

Post-Keynesianism is a tradition of long standing, so why are things different now? Certainly post-Keynesian economics has developed apace, as showcased by the admirable array of examples of new developments in this volume. Yet in the meantime the environment for economists has changed dramatically since the 2007-2009 crisis (the global financial crisis, or GFC). While the core principles of post-Keynesian economics have not changed, the way in which we can discuss the possibilities for this approach and the chances of being heard are very different from what they were 10 years ago. Here we aim to pause and reflect on these opportunities, and the challenges they pose, in order to consider the role of post Keynesianism at the cutting edge of understanding reality.

Not all economists would agree that the landscape has changed fundamentally. Some mainstream economists still regard the GFC as an aberration from a stable norm, requiring no further attention. Even Alan Greenspan, who admitted failings in not anticipating the crisis, still maintained that it was better to treat it as an aberration which inevitably brought costs, but did not require a new theoretical analysis or significant regulatory response (Andrews 2008). The standard DSGE modelling approach presumes stability, ruling out forecasting or analysis of instability, but is seen to come back into its own equilibrium path when the crisis has passed.

However, as Keynes (1923, p. 80) argued, '[e]conomists set themselves too easy, too useless a task if in tempestuous seasons they can only tell us that when the storm is long past the ocean is flat again'. Indeed for many mainstream economists the GFC has created a new challenge which they want to address. There is even some recognition of the responsibility mainstream economists must bear for encouraging the financial liberalisation which exacerbated the conditions for the crisis. Non-mainstream economists on the other hand readily understood the GFC as a case of 
the longstanding Minskyan theory of financial instability (Minsky 1992). Since that theory identifies the source of instability in periods of stability (as in the 'great moderation'), non-mainstream economists had long warned of the prospects for financial instability.

The GFC not only changed the economic landscape, but it also changed the political landscape, with knock-on effects for economics. Governments applied fiscal austerity, on the advice of mainstream economists, to address the fiscal effects of supporting failing banks. This created a popular backlash against banks which had created the problem in the first place and the politicians who had supported them. However, it also created a popular backlash against economists who had failed to predict the crisis and appeared to be struggling to explain it, while at the same time conveying tremendous confidence in the scientific worth of their theories. The result has been a general questioning of mainstream economics.

There has been a growing sense of unease among some mainstream economists, not only over DSGE models (see e.g. Hendry and Meullbauer 2017, Marchionatti and Sella 2017), but also more generally with models of the macroeconomy which have no place for money, finance or banks. As well as the resulting enrichment of some mainstream macroeconomic modelling on the monetary side, there has been growing theoretical interest in income distribution and its relationship with growth, and an increasing mainstream focus on applied statistics to account for real developments. However, the DSGE reliance instead on simulation is perpetuating the longstanding tension between pure and applied mainstream macroeconomics, while the underlying methodological approach remains unchanged.

In the meantime post-Keynesian economists were well placed to address popular concerns with money and banking, income distribution and sustainable growth, since theory was expressly designed for application rather than to fit internal 'scientific' criteria (see e.g. Arestis and Sawyer 1998). Arguments have thus been put forward against austerity (see e.g. Chick, Pettifor and Tily [2010] 2016), and advocating banking reform (see e.g. Dow 2012). Post-Keynesian economics offers an alternative body of theory which has continued to develop into a mature paradigm. The GFC constitutes the kind of glaring anomaly (relative to the dominant theory) which Kuhn ([1962] 1970) had suggested could lead to a scientific revolution, and post-Keynesian economics is an alternative paradigm waiting in the wings. However, an understanding of Kuhn as envisaging one orthodoxy replacing another arguably does not fit well with the nature of a social science and its complex, evolving subject matter. Post Keynesians are not alone among non-mainstream schools of thought in challenging the mainstream, and each of these other schools sees itself as offering a 
legitimate alternative. Indeed the perception of the GFC as an anomaly relative to mainstream theory is shared by the international groups of students who are working hard to steer, not just economics education, but economics itself, in a new, pluralist, direction. ${ }^{1}$

For post Keynesians there is a compelling argument for pluralism. Yet post Keynesians belong to that school because of a belief that it offers the best way forward. The current situation offers great opportunities for post Keynesianism to attempt to supplant mainstream economics. The power of the mainstream is indubitable, but, as Winston Churchill is supposed to have said during World War II, we must never let a good crisis go to waste. We therefore explore the opportunities for post-Keynesian economics below, considering first the alternative theories and policy ideas we can offer. We then consider post-Keynesian modelling as part of the methodological armoury, making the argument for mathematical modelling as part of a pluralist methodology, as against the only-modelling and no-modelling positions. However, we proceed by grappling with the argument that post Keynesianism should be pursued, not only with a pluralist methodology, but also within a pluralist landscape alongside other schools of thought. We finish with a discussion of the implications for economics education.

In what follows, some selected references are provided. However, since the paper involves an overview of post-Keynesian economics, the potential references are legion. The reader is encouraged to peruse Harcourt and Kriesler (2013a, b) on particular topics, as well as the reading lists provided on the Post Keynesian Economic Society website, https://www. postkeynesian.net/.

\subsection{THEORETICAL ALTERNATIVES AND IDEAS FOR ECONOMIC POLICY}

While the theoretical alternatives put forward by post Keynesians can be traced back to Keynes, there are additional strands of influence that have fostered a range of theories reflecting different emphases and different methods of enquiry (Hamouda and Harcourt [1988] 2003). Yet there is a shared set of core principles established as a result of concern to promote economic well-being combined with social justice. While maldistribution of income and economic power is a concern of long standing, the

1 These groups operate within overarching groupings, notably Rethinking Economics (www.rethinkeconomics.org/) and the INET Young Scholars Initiative (https://www.ineteco nomics.org/education/young-scholars-initiative). 
ecological aspect of economic well-being has become an increasing focus. Further, the environment has changed within which the core principles of post-Keynesian economics are to be applied, most notably developments within the financial sector and the growing concern with ecological issues (Chick, 2018).

A core element is the principle of effective demand. Following directly from Keynes, this principle is important for explaining the persistence of unemployment and the appropriate fiscal policy response. Following Kalecki the principle is also important for considering the drivers of economic growth (and productivity growth). In particular the principle of effective demand guides comparison between wage-led growth and profit-led growth in terms of which is the more effective as well as drawing implications for income distribution. This leads to the post-Keynesian argument for addressing the current situation of low productivity growth and maldistribution of income by boosting effective demand through increased wages and stopping fiscal austerity (not least because of its failings even in its own terms).

Investment plays a key role in effective demand, not least because of its volatility. Post Keynesians argue for boosting effective demand as the most effective way of encouraging private sector investment. Keynes emphasised the way in which uncertainty (unquantifiable risk) deters commitment to illiquidity - in this case to real investment. Uncertainty is endemic to open, organic social systems, and yet it can be managed up to a point, e.g. by promoting a stable economic and financial environment supported by appropriate institutions. This requires government involvement since monetary production systems are by their nature unstable. As Minsky (1992) argued, periods of stability in fact breed instability by encouraging unreasonable leveraging and unsustainable levels of debt.

Post-Keynesian theory already has a well-developed analysis of the money-finance-production nexus; it was the GFC which really exposed the problem with mainstream macroeconomic theories being conducted in real terms. Again this ranges from analysis of the cycle to long-term analysis, e.g. to the relationship between financial development and economic development, or to the effects of decades of a new wave of financialisation (see e.g. Stockhammer 2013). Within these analyses we see core features of post Keynesianism: the importance of institutional structures (configurations of central banking, bank regulation, etc.) and of uncertainty as having general application beyond firms' investment decisions.

Keynes's theory of liquidity preference applies in particular to behaviour within financial markets. As the Bretton Woods system broke down and financial markets were liberalised in the 1970s we saw the financial sector being restructured to protect itself from the ensuing uncertainty (while 
also seeking new profitable opportunities). Indeed the shift towards securitisation and active derivatives markets was actually spurred on by the new Basel capital requirements designed to curtail credit growth (Chick 2008). The aftermath of the GFC has likewise seen high liquidity preference and a reluctance of banks to extend credit to small and medium-sized enterprises, whose prospects they regard as particularly uncertain.

All this analysis is characterised by the post-Keynesian view that instability is the norm and that policy to mitigate it needs as much attention when markets seem stable as when there is a crisis. This involves a different view of the state. In mainstream theory the state is an exogenous force whose role is to correct or offset market imperfections. In post-Keynesian theory the state is an endemic, generally enabling, aspect of markets. For example the state provides (or should provide) the legal, institutional, regulatory and financial support for the innovations on which the production sector depends - the entrepreneurial state (Mazzucato 2013). Similarly central bank practices enable the financial sector by supervising and monitoring them and by providing lender-of-last-resort support, injecting liquidity in times of crisis. Bank regulation constrains practices and portfolio structures. However, since bank regulation is designed to constrain their excesses and the proliferation of instability through increasingly complex global networks, it ultimately enables the system to function. Given the post-Keynesian appreciation for the social role of money, leaving the banking system to its own devices and allowing it to collapse would create the mother of all constraints.

Post-Keynesian theory suggests a rounded approach to policy that recognises the importance of interdependence between the state and the private sector, and thus the importance of practices and institutional frameworks. This contrasts with the mainstream habit of thinking of the state as exogenous and designing policy frameworks accordingly, e.g. tasking an independent central bank with achieving an inflation target, or setting up a currency area (the Eurozone) with strict fiscal rules. In both cases post-Keynesian policy proposals recognise the interdependencies ignored by such strict separations, e.g. between monetary policy and fiscal policy.

However, it has become a political issue to question the validity of economic policy advice. This stems partly from the evident inability of mainstream economists to predict or explain the GFC (a charge from which post-Keynesian economists are exempt). Yet it also stems from underlying factors. First mainstream economics appeared detached from real experience, e.g. when downplaying the consequences for the most vulnerable in society of fiscal austerity and indeed not acknowledging the maldistribution of income. Second, forecasts were made with undue confidence 
belying the inherent uncertainty involved in any forecasting exercise. This reflects the positivist and scientistic approach within mainstream economics.

For all the furore which followed from Friedman's advocacy of instrumentalism, it now seems to be conventional among mainstream economists to emphasise prediction as their core activity. This stance has been encouraged by the shift towards empirical application, as in DSGE modelling, and away from an exclusive focus on pure theory. Yet, as Lawson (1997) has explained, this approach only makes sense when applied to a closed social system. For post Keynesians who take a political economy approach to understanding and explaining an open, organic social system, the scope for prediction is severely limited. Indeed the epistemological limitations imposed by an open subject matter require us to be modest about what can be concluded from economic theory. However, this theory can be enhanced by drawing on a range of cognate disciplines. Certainly mainstream economics has increasingly looked to other disciplines, but this work has been coloured by the professed need to incorporate these inputs into the conventional equilibrium framework, often as additional preferences or constraints.

A particular source of over-confidence in economic prediction arises from the mainstream view of their theory as being positive in the sense of value-free. It is up to economists, according to this view, to set out the predicted effects of policy moves independently of any political or moral views, the latter to be specified by politicians. Yet non-mainstream economists, including post Keynesians, have pointed out the values embedded in mainstream theorising: for example the privileging of a narrow understanding of efficiency such that competitive market wages are assumed to reflect the value of work. At the same time many post Keynesians are quite explicit about their value systems and how they affect their theorising (Geoff Harcourt being a notable example, see e.g. Harcourt 2001, especially chapter 1), recognising that others have different value systems.

The over-confidence of mainstream economists and the moral implications of their theories have become a matter for public discourse since the crisis. Post Keynesians can make a particular contribution by being more humble in our pronouncements and explaining why. Mainstream economists have been too successful in encouraging a dualistic view that their approach is the most scientific, such that qualified arguments and expression of moral values are by definition not science. This has fed into the popular dismissal of 'experts' and the perception of disagreement among economists as a sign of their being unscientific (see further Dow 2017). So post Keynesians need to address these issues of communication 
and engagement. Here they can draw on the practical suggestions put forward in the Earle, Moran and Ward-Perkins (2017) book which arose from the students' Rethinking Economics network.

\subsection{MODELLING IN POST-KEYNESIAN ECONOMICS}

A particular aspect of methodology that defines a difference between mainstream and post-Keynesian economics is the stance taken on mathematical modelling. Within mainstream economics, deductivist mathematics is the required method for deriving theoretical propositions. An argument in favour of this approach is that theories expressed in common form become commensurate, allowing direct comparability. However, since mathematical formalism is defined as the most scientific approach, it is held that anything which cannot be so expressed can be disregarded. The range of possible theories is thus circumscribed. Economics becomes defined by the deductivist mathematical method.

For many non-mainstream economists, such as neo-Austrians, mathematical modelling is regarded as unacceptable in that it precludes the aspects of social reality which are regarded as most important, such as creativity. Mathematical formalism is not neutral (Chick and Dow 2001). At a philosophical level, critical realists argue against the use of mathematical modelling on the grounds that it imposes closure on an open reality.

Yet post-Keynesian economics includes a range of analyses resting on mathematical modelling, and much of the progress in these analyses can be regarded as being cutting-edge. Further, with the growing unease about mainstream economics, this modelling is attracting increasing attention, not least because it is more readily accessible to mainstream economists than purely verbal analysis. So in this section we consider the general issue of mathematical modelling in post-Keynesian economics, how it differs from mainstream mathematical formalism and how it fits into post-Keynesian methodology.

Within mainstream economics, the dominant deductivist mathematical approach derives propositions from axioms about individual behaviour. Axioms of rational decision-making which were originally taken to be selfevident are now open to modification, as a result of experimental evidence, within the (new) behavioural economics. Nevertheless the goal remains to arrive at a (more complex) set of individual goals and constraints which would generate better testable propositions (see e.g. Camerer, Lowenstein and Rabin 2004, p. 1). While these modifications are a response to reality 
in the form of falsifying evidence, the priority is still to have theory conform to an axiomatic structure. It is the mathematical method which determines the nature of abstraction.

Post-Keynesian theory in contrast is realist in that it starts with an understanding of the nature of the subject matter and of the policy problems to be addressed and applies mathematical methods to suit. The clearest example of this difference is the absence of banks (and even sometimes money) from mainstream macroeconomic models, even when they were addressed to monetary policy. In other words no accommodation was made for analysing the transmission mechanism. Post-Keynesian macroeconomic theory addressed to monetary policy in contrast draws on a long tradition of endogenous money theory which has banks at its core, while theory addressed to financial instability focuses on the evolution of particular products and practices in order to understand particular cycle phases in particular contexts.

One of the difficulties in incorporating financial institutions in macro models is that institutional and regulatory structures and financial behaviour differ from one country to the next and from one era to another. These differences are difficult to model mathematically in such a way as to generate the kind of universal theory to which mainstream economics aspires. Yet if for example there is not one universal transmission mechanism then, if it is to be useful for policy purposes, theory needs to take that into account. Thus for example agent-based modelling, and complexity theory more generally, seek to incorporate institutions and other sources of specificity. Further post-Keynesian models, such as stock-flow consistent models, incorporate another feature of real socio-economic processes, which is that developments are often irreversible - there is hysteresis. This follows from the interaction between economic experience, behaviour and institutions and their evolution. Similarly, while post-Keynesian principles such as effective demand and liquidity preference carry across analysis of developed economies and developing economies, and across concerns with the short and long runs, the emphasis placed on each and the way in which they are analysed depends on the context.

There are several strands of modelling within post-Keynesian economics. Yet since none conforms to a deductivist structure, there is no scope for combining them within a single framework on a par with the mainstream general equilibrium framework. Each modelling approach in fact represents one element of a more pluralist methodology. In other words the propositions arising from any one model are not the final word on any subject. The universality of uncertainty within an open (socio-economic) system means that no deductivist structure can capture the whole. Yet the provisional closures which are necessary for any modelling allow 
us to separate out subsystems temporarily for mathematical analysis. Application then requires attention to those factors which have been left out:

The object of our analysis is, not to provide a machine, or method of blind manipulation, which will furnish an infallible answer, but to provide ourselves with an organised and orderly method of thinking out particular problems; and, after we have reached a provisional conclusion by isolating the complicating factors one by one, we than have to go back on ourselves and allow, as well as we can, for the probable interactions of the factors amongst themselves. (Keynes, 1936, p. 297)

Since the starting point for post-Keynesian theory is a realist one, based on an understanding of the subject matter as open and evolving, deductive mathematical argument can only have limited (if any) application. Keynes (1921) dismissed the case of certainty at the start of $A$ Treatise on Probability as a very special case, the general case being uncertainty. Building grounds for belief under uncertainty requires the application of multistranded human logic, since the scope for demonstrably true premises as the basis for classical logic was so limited. Argument therefore requires reason (which may be expressed mathematically) and evidence, but also conventional judgement, expert judgement, and intuition or animal spirits. Even economists require animal spirits, understood as the urge to make and stand by an argument, while knowing that the scope for demonstrating its truth is so limited. The more strands of argument point in one direction, the greater the weight attached to the argument. Yet new knowledge can reveal ignorance which had not been recognised, so that the weight of the argument may fall.

Just as decision-making in the economy requires multiple strands of argument, so does economic analysis itself. This is the argument for a pluralist methodology. Thus knowledge about an institutional structure in a particular context, or about the state of confidence at a particular time, requires non-mathematical methods of enquiry. Yet the knowledge so derived provides the 'real' jumping-off point for mathematical analysis. While mainstream economics invokes closure to conform to a general equilibrium framework, post-Keynesian analysis invokes closure as a simplification to narrow down the focus of a particular enquiry. However, when that analysis is to be used for policy advice, what has been kept at the 'back of one's mind' has to be brought to the fore: how far does the simplification abstract from something which could prove to be pivotal for the outcome of a policy? Sensitivity analysis tells us something, but really this exercise requires recourse to a range of methods - and possibly a range of other cognate disciplines. For example, theory might suggest that it was 
financial deregulation from the 1970s which exacerbated the conditions for crisis. However, is it possible to return to pre-1970s-style bank regulation, and how would institutions and financial behaviour respond, given all that has happened since the 1970s?

An issue which highlights the role of mathematical modelling is the question of whether theory should be built on microfoundations, macrofoundations or neither. A deductivist structure built on methodological individualism, like mainstream economics, requires microfoundations: the rationality axioms. Post-Keynesian theory is built on an understanding of the individual as being profoundly social, with behaviour conditioned by social conventions and institutions, as well as by macroeconomic conditions (with input also from individuality, e.g. in the form of creativity).

While many post Keynesians have chosen to express this importance of the macroeconomic level as 'macrofoundations', King (2012) has persuasively (to my mind) argued that to talk in terms of foundations is still to be deductivist (amenable to full capture by classical logic and deductivist mathematics). Rather he advocates a pluralist strategy of conducting some analysis at the micro level and some at the macro level depending on the problem at hand, while recognising the important interactions between each. He argues that we should think in terms of foundations instead at the philosophical level. It is at this level that the argument for a pluralist methodology - and methodological pluralism - arises. The former refers to employing a range of methods, of which mathematical modelling is one of many, while the latter refers to acknowledging the legitimacy of a range of approaches, of which post Keynesianism is one, and indeed fostering that plurality. This is controversial. Should we not focus on developing and promoting post-Keynesian theory? We address this issue through a discussion of economics teaching.

\subsection{PLURALISM IN ECONOMICS TEACHING}

When pluralism is proposed for economics teaching, clearly what is envisaged is something more than teaching a range of methods (as the basis for pluralist methodologies). It involves exposing students to a range of approaches, or paradigms, in economics, helping them to understand the epistemological basis for such a plurality, and providing them with the tools to form a view about these approaches for themselves (methodological pluralism). The concept of 'approach' applies to economic analysis at a variety of levels, encompassing understanding of reality (ontology), understanding of knowledge (epistemology), methodology, methods and theory. An approach therefore corresponds to a school of thought. 
The case for this kind of pluralist approach to teaching rests on the view that a plurality of approaches to economics provides a more robust basis for knowledge than monism (a single approach, which is the current norm) (Dow, 2018). The issue relates to considering economics as a science and how far it can follow the lead of the physical sciences in settling on one preferred scientific method. Were that possible, then it would be a matter, not of different paradigms, but of better and worse science. While even that is contestable for the physical sciences, it is certainly contestable for the social sciences. Lawson (1997) has most forcefully explored the weakness of the mainstream closed-system positivist approach, which he argues can only be coherent in application if its subject matter is a closed system. Social systems, however, are open in that structures and internal relations evolve in a non-deterministic way (extrinsic and intrinsic openness).

The case has been made above for provisional analytical closures in the form of models as one of many methods (which some critical realists would not accept). However, as partial analyses these models need to be considered along with analyses employing other methods in order to add weight to arguments about the likely effects of particular policies. Yet there is scope for a wide range of open-system approaches to economics (Chick and Dow 2005). Each approach accepts some closures (abstractions) while pursuing analysis of the processes central to a shared ontology. However, different ontologies focus on different aspects of an open-system reality - the individual entrepreneur, class, institutions, unemployment, etc. The chosen focus in turn requires a particular selection of methods of analysis, i.e. a particular pluralist methodology.

Having a range of approaches to economics makes the discipline more robust. Since each approach addresses what is understood (ontologically) to be the most important aspect of open-system reality, inevitably some circumstances will be more directly addressed by one approach than by the rest. This is the equivalent of the argument for biological diversity, that a species has a better chance of survival in the face of unforeseen developments if there are different strains, some of which will be better suited than others to the new environment. Yet even if an approach is put forward as being preferable in a wide variety of circumstances, its development alongside alternatives will be stronger than if there were no alternatives. Since each approach, by definition of an open subject matter, is inevitably partial, it is always contestable. To promote a particular approach we need to understand the foundations of that approach, and understand alternatives well enough to engage in meaningful debate with a chance to succeed in persuasion. Indeed the practice of interchange between approaches, albeit limited by their inherent incommensurabilities, promotes the crossfertilisation of ideas which lead to fruitful new developments. 
This holds clear implications for economics education. First it requires students to acquire methodological awareness, as a basis, not just for understanding the methodologies employed by different approaches, but also to understand pluralism itself. This requires an appreciation of 'otherness' (that no one approach can reasonably claim a monopoly), something which can be learned from the study of the history of economic thought. Further, training in methodology provides the basis for acquiring knowledge about the content and relative merits of the methodology of different approaches. Learning about at least two approaches, such as the mainstream and post-Keynesian approaches, allows students to learn how to compare, for example by means of debate. Further, debate helps students to appreciate layers of argument, allowing them to go beyond a dualistic sense that one side of the debate is right and the other wrong. Debates can be most effective when addressed to policy questions. Basing comparisons and debates on how different approaches address practical policy issues is not only motivating for students, but is in any case the ultimate point of understanding economics. The resulting methodological awareness, and the more rounded understanding of the possibilities for economics that follows, should then equip students for making their own choice of approach (or development of new synthetic approaches) as their economics careers develop.

None of this is incompatible with a strongly held view that postKeynesian economics is the best approach. Whichever approach we choose to adopt is by definition the one we think best. Methodological pluralism does not mean 'anything goes'. Rather it means that, in arguing that our chosen approach is best, we respect the legitimacy of alternatives, given that our own approach cannot be demonstrated categorically to be best. Any one approach inevitably illuminates understanding only from one perspective, abstracting from factors which may be important to other approaches. However, that by no means precludes strong argument in favour of the chosen approach. It is an important argument for methodological pluralism that, by requiring such debate, each approach is strengthened. Understanding of the chosen approach is strengthened, while understanding of alternatives can provide valuable insights for the further evolution of the chosen approach.

\subsection{CONCLUSION}

Learning more than one approach thus strengthens understanding of post Keynesianism, just as living in a foreign country strengthens understanding of the home country. Nevertheless for post Keynesians the priority is to educate students in post-Keynesian economics (see further Jespersen 
and Madsen 2013 and Chapters 12 and 13 in this volume). It is inherent to the post-Keynesian approach that theory and policy should reflect real context, such that both should correspond to context. Yet the core principles of effective demand and social justice, and the methodological approach best suited to applying those principles, are general. Much can be learned from studying the history of post Keynesianism (as in King 2002). Seeing how these principles were applied to other contexts than our own gives us ideas as to how to develop theory and policy in the modern context. Post Keynesianism is always 'progressive' in terms of aiming to be the best approach to address current problems directly.

Yet post Keynesianism has also always been at the frontier in the sense of not being widely understood and accepted. The 'Keynesianism' which held sway in the 1950s and 1960s differed fundamentally from Keynes's own approach. However, since that approach built on the ubiquity of uncertainty in an open, evolving economic system, it now increasingly resonates in a context of widespread and recognised uncertainty. Indeed post-Keynesian theory is commanding more attention, given its capacity to explain the causes of the crisis and to address current issues of stagnation and social injustice.

However, this increasing attention to more approaches is occurring against a backdrop of a monistic tradition in economics which assumes that there is one best approach. Further the idea still persists of economics as a technical discipline which aims to generate policy conclusions from universally applicable formal mathematical models. It is thus critical that efforts be redoubled to increase methodological awareness so that the post-Keynesian methodological approach can be properly understood.

Happily, alongside the growing interest in post-Keynesian economics are forces for an increasing general awareness of the need for a plurality of approaches. This has been driven partly by public bodies, such as central banks, looking beyond mainstream economics (and particularly DSGE models) for guidance. However, a major further push has been given by the international student movement. Since the members of this movement are the current 'market' for economics training, and also the future generation of economics educators, there is hope for the future, in which post-Keynesian economics will continue to progress and be progressive.

\section{ACKNOWLEDGEMENT}

I am grateful for comments following presentation of this paper to the Fourth Nordic Post Keynesian Conference, Aalborg, April 2017, and particularly from Jesper Jespersen. 


\section{REFERENCES}

Andrews, E.L. (2008) 'Greenspan concedes error on regulation', New York Times, 23 October, available at http://www.nytimes.com/2008/10/24/business/economy /24panel.html, accessed 22 November 2017.

Arestis, P. and M. Sawyer (1998) 'Keynesian economic policies for the new millennium', Economic Journal, 108 (446), 181-95.

Camerer, C.F., G. Lowenstein and M. Rabin (2004) Advances in Behavioral Economics. Princeton, NJ: Princeton University Press.

Chick, V. (2008) 'Could the crisis at Northern Rock have been predicted?: An evolutionary approach', Contributions to Political Economy, 27 (1), 115-24.

Chick, V. (2018) 'The relevance of The General Theory at 80: Economic change and economic theory', in S. Dow, J. Jespersen and G. Tily (eds), The General Theory and Keynes for the 21st Century, pp. 1-15. Cheltenham, UK and Northampton, MA, USA: Edward Elgar Publishing.

Chick, V. and S.C. Dow (2001) 'Formalism, logic and reality: A Keynesian analysis', Cambridge Journal of Economics, 25 (6), 705-22.

Chick, V. and S.C. Dow (2005) 'The meaning of open systems', Journal of Economic Methodology, 12(3), 363-81.

Chick, V., A. Pettifor and G. Tily ([2010] 2016) The Economic Consequences of Mr Osborne, Prime e-book, available at https://static1.squarespace.com/static/541ff5f5 e4b02b7c37f31ed6/t/57a1d0e2e4fcb5198839a01f/1470222565804/The+Economic + Consequences + of $+\mathrm{Mr}+$ Osborne $+2016+$ final+v2-8.pdf, accessed 24 November 2017.

Dow, S.C. (2012) 'What are banks and bank regulation for? A consideration of the foundations for reform', European Journal of Economics and Economic Policies: Intervention, 9 (1), 39-56.

Dow, S.C. (2017) 'People have had enough of experts', INET Symposium on Experts, February, https://www.ineteconomics.org/perspectives/blog/people-have-had-eno ugh-of-experts http://hdl.handle.net/1893/25180

Dow, S.C. (2018) 'Pluralist economics: Is it scientific?', in S. Decker, W. Elsner and S. Flechtner (eds), Advancing Pluralism in Teaching Economics: International Perspectives on a Textbook Science. London: Routledge, pp. 13-30.

Earle, J., C. Moran and Z. Ward-Perkins (2017) The Econocracy: On the Perils of Leaving Economics to the Experts. Manchester: Manchester University Press.

Hamouda, O.F. and G.C. Harcourt ([1988] 2003) 'Post-Keynesianism: From criticism to coherence?', Bulletin of Economic Research, 40 (1), 1-33, reprinted in C. Sardoni (ed.), On Political Economists and Modern Political Economy: Selected Essays of G. C. Harcourt. Routledge: London, pp. 209-32.

Harcourt, G.C. (2001) 50 Years a Keynesian and Other Essays. London: Palgrave.

Harcourt, G.C. and P. Kriesler (eds) (2013a) The Oxford Handbook of Post-Keynesian Economics, Vol. 1: Theory and Origins. Oxford: Oxford University Press.

Harcourt, G.C. and P. Kriesler (eds) (2013b) The Oxford Handbook of Post-Keynesian Economics, Vol. 2: Critiques and Methodology. Oxford: Oxford University Press.

Hendry, D.F. and J.N.J. Meullbauer (2017) 'The future of macroeconomics: Macro theory and models at the Bank of England', University of Oxford Department of Economics, Discussion Paper no. 832.

Jespersen, J. and M.O. Madsen (eds) (2013) Teaching Post Keynesian Economics. Cheltenham, UK and Northampton, MA, USA: Edward Elgar Publishing. 
Keynes, J.M. (1921) A Treatise on Probability. London: Macmillan.

Keynes, J.M. (1923) A Tract on Monetary Reform. London: Macmillan.

Keynes, J.M. (1936) The General Theory of Employment, Interest and Money. London: Macmillan.

King, J.E. (2002) A History of Post Keynesian Economics since 1936. Cheltenham, UK and Northampton, MA, USA: Edward Elgar Publishing.

King, J.E. (2012) The Microfoundations Delusion. Cheltenham, UK and Northampton, MA, USA: Edward Elgar Publishing.

Kuhn, T.S. ([1962] 1970) The Structure of Scientific Revolutions. Chicago, IL: Chicago University Press.

Lawson, T. (1997) Economics and Reality. London: Routledge.

Marchionatti, R. and L. Sella (2017) 'Is neo-Walrasian macroeconom(etr)ics a dead end? An assessment of recent criticisms of DSGE models', Journal of Post Keynesian Economics, available at http://dx.doi.org/10.1080/01603477.2017.1319 250, accessed 24 November 2017.

Mazzucato, M. (2013) The Entrepreneurial State. London: Anthem Press.

Minsky, H.P. (1992) 'The financial instability hypothesis', Working Paper 74, The Levy Economics Institute, available at http://www.levyinstitute.org/pubs/wp74. pdf, accessed 24 November 2017.

Stockhammer, E. (2013) 'Financialization and the global economy', in G. Epstein and M. Wolfson (eds), The Handbook of the Political Economy of Financial Crises. New York: Oxford University Press, ch. 25. 